\title{
Modern Materials in Surgical Correction of Genital Prolapse
}

\author{
Ishchenko $\mathrm{AA}^{1,3}$, Ishchenko $\mathrm{AI}^{1,2 *}$ and Gilyadova $\mathrm{AV}^{1,3}$ \\ ${ }^{1}$ The Federal State Autonomous Educational Institution of Higher Education IM, Sechenov University, Russia \\ ${ }^{2}$ The clinic of obstetrics and gynecology, Sechenov First Moscow State Medical University, Moscow \\ ${ }^{3}$ Department of Oncogynecology, Sechenov University, Moscow
}

Submission: August 24, 2018; Published: September 14, 2018

${ }^{*}$ Corresponding author: Ishchenko Anton Anatolievich, Candidate of Medical Sciences, Head of Oncogynecology Department of the University Clinical Hospital No. 4 ofthe Federal State Autonomous Educational Institution of Higher Education "I.M. Sechenov First Moscow State Medical University" of the Ministry of Health of Russia (Sechenov University), Moscow, Tel: +79161150634; Email: ra2001_2001@mail.ru

\begin{abstract}
Genital prolapse is a disease manifested by the displacement of the uterus and the vaginal walls to the genital slit and/or by going beyond it. At the basis of this pathology lies the dysfunctionalityof the ligament apparatus of the internal genital organs and the muscles of the pelvic floor. The causes of this pathology include physical, genetic, age, hormonal factors. Pelvic prolapse is a very urgent problem, due to the high incidence in bothpatientof thereproductive age and postmenopausal women, as well as the projected increase in morbidity in countries with excessive fertility and in countries with a high life expectancy. The most preferred method of treatment is surgical correction, based on neofasciogenesis with the use of gridimplants. In this study, 37 operations were performed using a titanium implant, wherethe patients were divided into three groups[1-4]. The patients of the first group underwent a modification of the Manchester operation with fixation of the uterus through the membrane of the obturator opening with use titanium implant. Patients of the second group underwent a colposuspension using a titanium implant when was been performing vaginal extirpation of the uterus. In the third group of patientswas performed the correction of cystocele with using trapezoidal titanium implants. The observation time was 8 to 10 months.During this periodneither recurrence of the diseaseno complications was observed. Evaluation of the results was based on complaints, clinical and diagnostic data (ultrasound ofperineum, MRI with functional tests)[5-11]. This study demonstrated the perspectiveof using titanium implants, due to the presence of a number of advantages over polypropylene.
\end{abstract}

Keywords: Genital prolapse;Cystocele;Gridimplant;Titanium implant;Colposuspension;Vaginal hysterectomy;Total uterine prolapse

\section{Introduction}

The genital prolapse is currently a very urgent problem. The problem of changes in the anatomical connections of the pelvic organs of women and their functions, due to the impact on the tissues of the reproductive system of certain factors, such as childbirth, genetics and lifestyle, has not yet been solved. According to various authors the prevalence of this disease is from 28 to $50 \%[12,13]$.

It should be noted that aboutthe third of patients is of reproductive age. This means that in countries with high fertility, the morbidity will increase.Due to the increase in lifespan in countries with highly effective medicine, there is an increase in the number of elderly patients with prolapse. Therefore, it can be assumed that the prevalence of genital hernias will increase significantly in the coming decades.One of the main methods of treatment the prolapse of pelvic organ is surgical correction[14-18].In recent years, the operative gynecology has developed a large number of combined techniques aimed at the prevention of the prolapse of female organs and the treatment of prolapse of vaginal wall and the prolapse of the dome of the vagina with the application of synthetic implants.The studies have shown high efficiency of the proposed methods, low number of complications and relapses[19-22].

Despite the fact that according to a Meta-analysis of the Cochrane collaboration, the most effective method of treatment of genital prolapse is promontofixation, the technical complexity of carrying out of promontofixation, as well as the impossibility and the inexpediency of its use at some patients, does not allow to consider the promontofixation is the gold standard in the treatment of prolapse of female pelvic organs[22-27].

Since latelychoosing surgical methods of treatmentwe prefer technologies based on the creation of a new artificial fasciawith the use of frame systems of various extraneous material. At the momentin Russia there are several surgical methodswhich are based on the use of polypropylene implant[28]. 
This material has a number of advantages over other synthetic analogues and pork dermal flap. However, the use of polypropylene implants in gynecology revealed a number of complications associated with the feature of the material[29].

In particular, infectious complications, erosion and protrusion of the material as a result of rejection of artificial tissue.The frequency of the latter can be up to $6 \%$ according to various data.This necessitates the search for new materials for this type of operations with greater inertia to the surrounding tissues.One of these materials is titanium.For more than 10 years, titanium mesh implants have been used in surgery to treat hernias. And also, in orthopedics and dentistry[30]. The data accumulated over the past years allow us to consider titanium silk as an alternative to polypropylene.

\section{Materials and Methods}

By now we have performed 37 surgical interventions in three major clinics in Moscow for women with various forms of genital prolapse using titanium silk as an implant.

Amongthese operations12 patients underwent modification of Manchester surgery with fixation of the uterus through the obturator membrane by means of titanium mesh implants. Modification of the Manchester operation was initially developed with the use of Prolene mesh implant and have proved effective compared with standard the Manchester operation. A feature of this modification is the installation of the implant through the obturator membrane with fixation of the implant base to the cervical stump. Being a new ligament, the implant duplicates the stumps of cardinal ligaments, thereby holding the uterus in a certain position[31].

Whileusing a polypropylene flap we achieved a reduction in relapsesin comparison with the traditional technique. We didn't receiving significant complications in the early and late postoperative period. However, several patients noted pain syndrome that occurred in the early postoperative period.

Theresearchoftitanium silk andobservationofpatients for 8-12 months,didn't reveal any recurrence of the disease. Also, there was not a single case of erosion or suppuration of the implants, as well as dysparinia, or pain syndrome. In 8 cases we used titanium implants performing colposuspension during vaginal extirpation in women with complete and incomplete uterine prolapse. This is a unique technique developed and implemented by a team of authors of our Department of our University[32].

In this case titanium tapes are arranged crossways.They are fixed to the sacrospinal ligaments and excreted through the obturator membrane and muscle from the contralateral side. The place of crossing of the tapes falls on the dome of the vaginawhich ultimately is an additional supportpreventing the developmentabaissementof thevagina dome[33].
The monitoring period of this group of patients ranged from 8 to 10 months. At this stagewe didn't have any MESH-associated complication.The last group of patients was represented by 17 women who underwent correction of cystocele using trapezoidal titanium implant, established by the original technique.In this group there were mainly patients with isolated cystocele of II-III degree. To determine the size of the implant, we used the ultrasound of perineal,MRI with functional tests, as well as intraoperative morphometry.

This allowed us to minimize the size of the implant. And given the features of the titanium mesh we can to simulated the shape of the future fascia.In this group of patients there were no complications at the moment. The period of monitoring was 8-10 months.The assessment of the location of titanium mesh in the postoperative period was estimated by ultrasound of the perineum.

\section{Discussion}

The obtained clinical data allow us to assert that the titanium implant has a number of advantages in its use in pelvic surgery, compared with polypropylene. Similar conclusions were reached by our colleagues involved in the surgery of abdominal hernias, as well as orthopedists using titanium silk in their practice. All this allowed to highlight and to explain the benefits of this material compared to polypropylene.

The main features of the implantmade of titanium:

a) Biological inertness (only platinum is more inert). No complications of infectious and allergic genesis

b) The feature of the netting titanium implant allows connective tissue to integrate into the net as much as possible.

c) Formation of type 1 collagen. The collagen of the fist type leads to the formation of ripe connective tissue. In the result, a thin and very dense scar is formed.Whileusing polypropylene materialsthe collagen of thethird type is formed, which in its turn form of immature connective tissue. This leads toa rough scar.

d) Absent aseptic (serous) inflammation.

e) The possibility of application of titanium implants in the presence of an inflammatory process in the tissues. With adequate antibiotic therapy, titanium "takes root" well without causing adhesion of microorganisms and without being a nutrient medium for them.

f) The possibility of use in the elderly and cancer patients (a group of patients with weakened immunity). The cascade reaction of theimmune system doesn'thappen whileusing titanium nets. In addition, titanium, unlike polypropylene, is not subjected to destructionduring chemotherapy 
g) No changes during long-term observation (polypropylene partially destroyed after 5-6 years which leads to" wrinkling "of the grid due to the" low "quality connective tissue scar, andwhichcausesa sense of "foreign body"and usually chronic pain syndrome).

\section{Conclusion}

Thus, it should be noted that the use of titanium implants in pelvic surgery, is a highly effective method of correction of genital prolapse and itdoes not have a number of side effects that are typical for polypropelene. This allows us to hope that in the future new technologies will improve the results of treatment of pelvic organ prolapse in women.

\section{References}

1. Parshikov VV, Samsonov AV, Romanov RV, Degree VP, Samsonov AA, et al. (2011) Plastic of abdominal wall by meshes in the "Titanium silk" Materials of IX conference "Topical issues of herniology". Moscow, pp. 157-159.

2. Parshikov VV, Samsonov AV, Romanov RV, Degree VP, Samsonov AA, et al. (2012) The first experience of abdominal wall plasty with prosthetic implants "Titanium silk". V V Medical almanac 1: 107-109.

3. Lazovsky SD, Charles DI, Kazantsev AA (2012) Recovery of the tendon of the rectus muscle of femoris by titanium mesh for reinforcing plastics of soft tissues "Titanium silk". Proceedings of the III Congress of traumatologists and orthopaedists of the Ural Federal district. Yekaterinburg.

4. Lemonov AV, Titov DA, Zabrodin VV, Valiev EF (2014) Medical Bulletin of the Ministry of internal Affairs. The first clinical experience of application of mesh implant made of titanium threads in the alloplasty of inguinal hernias in the employees of the interior Ministry, the Ministry of emergency situations №1, pp. 49-51.

5. Zhuravlev VP, Kazakov AV, Kazantsev AA (2015) The Use of suture material "Titanal" in the surgical treatment of chronic generalized periodontitis. Medical science and education of the Urals № 1.

6. Kazantsev AA, Parshikov VV, Mironov AA, Alekhin AI (2016) Titaniumcontaining mesh implants as a promising group of materials for hernioplasty. (Literature review.) Surgery. Journal named after N. I. Pirogov 4: 40-48.

7. Parshikov VV, Mironov AA, Anikina EA, Zaslavskaya MI, Alekhin AI, et al. (2015) Prosthetic abdominal wall plasty using light and ultra-light synthetic and titanium-containing materials in conditions of high bacterial contamination (experimental study). Modern technologies in medicine 7(4): 64-71.

8. Parshikov VV, Mironov AA, Anikina EA, Zaslavskaya MI, Alekhin AI, et al. (2016) Intraperitoneal and retromuscular plasty of the abdominal wall with ultra-light polypropylene and titanium-containing endoprostheses (experimental study) Surgery. Magazine them. N and Pirogov 4: 40-48.

9. Babichenko II, Kazantsev AA, Titorov DL, Shemyatovsky KA, Gevondyan NM, et al. (2016) Influence of titanium coating on the biocompatibility of mesh implants made of polypropylene. Cytology 58(1): 44-51.

10. Parshikov VV, Mironov AA, Anikina EA, Zaslavskaya MI, Alekhin AI, et al. (2016) To the question about the possibility of using an ultralightweight titanium mesh implants for abdominal wall plasty in terms of infection (experimental study) Surgery 11: 64-70.
11. Kolpakov AA, Kazantsev AA (2015) Comparative analysis of the results of the use of prostheses "titanium silk" and polypropylene in patients with postoperative ventral hernias 13: 774 .

12. Parshikov VV (2012) Retromuscular plastic surgery of the abdominal wall with mesh. Fundamental study 7(1): 159-163.

13. Parshikov VV (2012) Plastic inguinal canal and reproductive health of men. The National Congress of Plastic surgery, p. 191.

14. Chernov AV (2012) Study of features of integration of various biomaterials in soft and bone tissues of the body. Genius of orthopedics 1: 97-101.

15. Sarbayeva NN (2013) Activation the peritoneal macrophages of rat on the surface of endoprostheses used for hernioplasty. Technology of living systems 10(8): 84-90.

16. Ponomarev YV, Volova LT, Belokonev VI, Milanova MN (2016) The role of the proteomic spectrum in predicting the biocompatibility of prosthetic materials. The first all-Russian Congress of herniologists. Moscow.

17. Khodakov VV, Zabrodin VV, Zabrodin EV (2016) The assessment of the effectiveness of alloplastic of the inguinal canal with the use of titanium mesh implants. Medical Bulletin of the Ministry of internal Affairs № 6, pp. 13-17.

18. Gevondyan NM, Kazantsev AA, Titorov DL, Semovski KA, Protasov AB, et al. (2015) Experimental study of the influence of titanium and polypropylene mesh implants on the adaptive immunity. Conference "The actualy problems of herniology".

19. Magomedov MM, Imanaliev MR, Ismailov GM (2016) Comparative Evaluation of Different Methods of Surgical Treatment of Postoperative Ventral Hernias. Bulletin of the Kyrgyz-Russian Slavic University. 16(11): 43-45.

20. Magomedov MM, Ismailov GM, Magomedbekov RE (2016) The contents of matrix metalloproteinases and their inhibitors before and after herniotomy with use prosthesis. Questions of biological, medical and pharmaceutical chemistry 3: 41-46.

21. Magomedov MM, Magomedbekov RE (2015) The Characteristics of Cytokine Status in the Patients with Inguinal Hernias Using Prosthetic Implants. Cytokines and inflammation 14(4): 45-49.

22. Losi P, Burchielli S, Spiller D, Finotti V, Kull S, et al. (2010) Cyanoacrylate surgical glue as an alternative to suture threads for mesh fixation in hernia repair. J Surg Res 163(2): e53-e58.

23. Hazebroek EJ, Ng A, Yong DH, Berry H, Leibman S, Smith GS (2008) Clinical evaluation of laparoscopic repair of large hiatal hernias with TiMesh. ANZ J Surg 78(10): 914-917.

24. Hazebroek EJ, Ng A, Yong DH, Berry H, Leibman S, Smith GS (2008) Evaluation of lightweight titanium-coated polypropylene mesh (TiMesh) for laparoscopic repair of large hiatal hernias. Surg Endosc 22(11): 2428-2432.

25. Schug-Pass C, Tamme C, Tannapfel A, Köckerling F (2006) A lightweight polypropylene mesh (TiMesh) for laparoscopic intraperitoneal repair of abdominal wall hernias: comparison of biocompatibility with the Dual Mesh in an experimental study using the porcine model. Surg Endosc 20(3): 402-409.

26. Schopf S, von Ahnen T, von Ahnen M, Schardey H (2011) Chronic pain after laparoscopic transabdominal preperitoneal hernia repair: a randomized comparison of light and extralight titanized polypropylene mesh. World J Surg 35(2): 302-310. 
27. Fortelny RH, Petter-Puchner AH, Gruber-Blum S, Mika K, Brand J (2011) The Feasibility of FS Mesh Fixation by a Transgastric ApproachAn Important Benefit in Future NOTES Procedures? J Surg Res 171(1): 80-86.

28. Kanellos D, Moesta KT, Schug-Pass C, Köckerling F (2010) Hiatoplasty Reinforcement by Means of a Lightweight Titanized Polypropylene Mesh Fixed with Fibrin Glue. Zentralbl Chir 136(3):244-248.

29. Fortelny RH, Petter-Puchner AH, Glaser KS, Keibl C, Gruber-Blum S, et al. (2010) Fibrin sealant (Tisseel) for hiatal mesh fixation in an experimental model in pigs. J Surg Res 162(1): 68-74.

30. Horstmann R, Hellwig M, Classen C, Röttgermann S, Palmes D (2006) Impact of polypropylene amount on functional outcome and quality of life after inguinal hernia repair by the TAPP procedure using pure, mixed, and titanium-coated meshes. World J Surg 30(9): 1742-1749.
31. Fortelny RH, Petter-Puchner AH, Glaser KS (2009) Fibrin sealant (Tissucol) for the fixation of hiatal mesh in the repair of giant paraesophageal hernia: a case report. Surg Laparosc Endosc Percutan Tech 19(3): e91-e94.

32. Scheidbach H, Tannapfel A, Schmidt U, Lippert H, Köckerling F (2004) Influence of titanium coating on the biocompatibility of a heavyweight polypropylene mesh. An animal experimental model. Eur Surg Res 36(5): 313-317.

33. Scheidbach H, Tamme C, Tannapfel A, Lippert H, Köckerling F (2004) In vivo studies comparing the biocompatibility of various polypropylene meshes and their handling properties during endoscopic total extraperitoneal (TEP) patchplasty: an experimental study in pigs. Surg Endosc 18(2): 211-220.

\begin{tabular}{|l|}
\hline \multicolumn{1}{|c|}{ Your next submission with Juniper Publishers } \\
will reach you the below assets \\
- Quality Editorial service \\
- Swift Peer Review \\
- Reprints availability \\
- E-prints Service \\
- Manuscript Podcast for convenient understanding \\
- Global attainment for your research \\
- Manuscript accessibility in different formats \\
( Pdf, E-pub, Full Text, Audio) \\
- Unceasing customer service \\
Track the below URL for one-step submission \\
https://juniperpublishers.com/online-submission.php \\
\hline
\end{tabular}

